\title{
POLSKA I JAPONIA PO II WOJNIE ŚWIATOWEJ. W 60. ROCZNICĘ WZNOWIENIA STOSUNKÓW OFICJALNYCH ${ }^{1}$
}

\author{
Ewa Pałasz-Rutkowska \\ Uniwersytet Warszawski
}

\begin{abstract}
POLAND AND JAPAN AFTER THE SECOND WORLD WAR. ON THE $60^{\text {TH }}$ ANNIVERSARY OF REESTABLISHING OFFICIAL RELATIONS
\end{abstract}

The official relations between Poland and Japan started in 1919. Throughout the entire interwar era, till December 1945, when Poland declared war on Japan, they were friendly, although due to geopolitical conditions not especially intense. After the war, the Iron Curtain fell deeper between East and West, and the division between the two camps became sharper. Post-war Poland became totally dependent on the USSR, which impacted the Polish foreign policy towards Japan. This paper examines the negotiations between Poland and Japan which proceeded in the years 1947-1957, and the problem of reestablishing official relations between the two countries after the war.

Key words: Poland, Japan, peace treaty, official diplomatic relations, Cold War.

Słowa kluczowe: Polska, Japonia, traktat pokojowy, oficjalne stosunki dyplomatyczne, zimna wojna.

W 2017 roku obchodzimy 60. rocznicę wznowienia oficjalnych stosunków dyplomatycznych między Polską a Japonią. Jest to więc świetna okazja, by wyjaśnić, dlaczego nastąpiło to dopiero w roku 1957, czyli 12 lat po zakończeniu II wojny światowej i dopiero 6 po tym, jak większość państw walczących w wojnie po przeciwnej stronie niż Japonia podpisała z nią traktat pokojowy. Historycznie nasze stosunki dwustronne układały się dobrze, choć były dość krótkie i ograniczone ze względu na sytuację geopolityczną, odległość geograficzną oraz preferencje

1 Niniejszy tekst powstał na podstawie badań prowadzonych w ramach finansowanego przez Narodowe Centrum Nauki projektu badawczego nr 2015/19/B/HS3/02072.

Adres do korespondencji: e.palasz-rutkowska@uw.edu.pl 
w polityce zagranicznej ${ }^{2}$. Rząd Japonii uznał niepodległe państwo polskie 6 marca 1919 roku, co przekazano stronie polskiej 22 marca i dlatego te dwie daty uznawane są za początek naszych oficjalnych kontaktów dwustronnych ${ }^{3}$. Początkowo nie były one zbyt intensywne, ale nasiliły się w latach 30 ., kiedy sytuacja w Europie sprawiła, że Polska stała się dla Japonii doskonałym źródłem informacji na temat jej sąsiadów, ZSRS i Niemiec. Doceniano też wiedzę i umiejętności oficerów polskiego wywiadu. Gdy 1 września 1939 roku rozpoczęła się II wojna światowa, Japonia ogłosiła neutralność i nadal, niemal do końca 1941 roku, utrzymywała z Polską przyjazne stosunki. Wbrew swoim sojusznikom, Niemcom i Włochom, z którymi we wrześniu 1940 roku podpisała pakt trzech, godząc się na tworzenie przez nich nowego porządku w Europie, pozwalała na oficjalne działanie ambasady RP w Tokio. Zmieniła swe nastawienie dopiero rok później, naciskana przez Niemców, którzy w tym czasie, po pierwszych zwycięstwach w wojnie przeciw ZSRS, zajęli całą Polskę i chcieli, by zniknęła ona z mapy świata. Ponieważ Japończycy szykowali się już także do wojny przeciw aliantom, 4 października 1941 roku rząd wycofał uznanie dla ambasadora RP i zamknął placówkę w Tokio, oficjalnie zlikwidowano także ambasadę Japonii w Warszawie. Praktycznie nie działała ona już od końca września 1939 roku. Stosunki obustronne zostały oficjalnie zerwane 11 grudnia, trzy dni po ataku japońskiej marynarki wojennej na bazę amerykańską w Pearl Harbor. Choć nadal trwała nieoficjalna współpraca polskiego i japońskiego wywiadu wojskowego, Polska, tak jak wcześniej jej sojusznicy, Wielka Brytania i Stany Zjednoczone, ogłosiła stan wojny z Japoniąa ${ }^{4}$.

Ostatecznie działania zbrojne Japonii w Azji i na Pacyfiku zakończyły się jej klęską i 15 sierpnia 1945 roku cesarz Hirohito (1901-1989, pośmiertnie Shōwa) ogłosił kapitulację. Władze godziły się na jej warunki uzgodnione podczas konferencji w Poczdamie (17 lipca - 2 sierpnia 1945 r.) przez prezydenta Stanów Zjednoczonych Harry'ego Trumana (1884-1972), premiera Wielkiej Brytanii Winstona Churchilla (1874-1965), którego zastąpił Clement Attlee (1883-1967), i przywódcę ZSRS Józefa Stalina (1874-1953). Ale Deklarację poczdamska sygnowali tylko przedstawiciele Stanów Zjednoczonych i Wielkiej Brytanii oraz za pomocą depeszy Jiang Jieshi (1887-1975), wspierany przez aliantów prezydent Narodowego Rządu Republiki Chińskiej ${ }^{5}$. Podpis Stalina byłby naruszeniem prawa, gdyż ZSRS nie był jeszcze w stanie wojny z Japonią. Przystąpił do niej dopiero 8 sierpnia 1945 roku, naruszając obowiązujący nadal traktat o neutralności z kwietnia 1941 roku. 2 września przedstawiciele Japonii podpisali akt kapitulacji. Zaczęła się okupacja kraju przez

2 Więcej na temat stosunków Polski z Japonią w: E. Pałasz-Rutkowska, A.T. Romer, Historia stosunków polsko-japońskich 1904-1945, Warszawa 2009.

3 Por. dokumenty w zespole Komitet Narodowy Polski-Paryż, s. 31-35, Archiwum Akt Nowych, Warszawa oraz Taishō hachinen sangatsu muika no kakugi kettei (Decyzja gabinetu z 6 marca 1919 r.) [w:] 1.4.3.17, Ōshū sensō kankei Pōrando mondai ikken (Sprawa Polski w związku z wojną w Europie), Gaimushō Gaikō Shiryōkan (Archiwum Dyplomatyczne MSZ; dalej jako GGS), Tokio.

4 „Dziennik Ustaw Rzeczypospolitej Polskiej” 1941, nr 8, Londyn.

5 Deklaracja poczdamska [w:] Zbiór dokumentów, Polski Instytut Spraw Międzynarodowych, Warszawa (dalej jako ZdPISM), 1951, nr 9-10, dok. 129, s. 1540-1544. 
Siły Sojusznicze, a praktycznie przez wojska amerykańskie, na których czele stanął generał Douglas MacArthur (1880-1964) ${ }^{6}$. Od początku nie chciał dopuścić Moskwy do decydowania o sprawach Japonii, aby uniknąć sytuacji podobnej do tej, która zaistniała po wojnie w Europie, gdzie powstały wyraźne strefy wpływów przeciwnych sobie systemów politycznych.

A podział na dwa obozy - kapitalistyczny i komunistyczny/socjalistyczny stawał się coraz bardziej wyraźny, żelazna kurtyna zapadała coraz głębiej między Wschodem a Zachodem. Wpływała na to także walka o strefy wpływów w Europie i Azji. W wyniku wojny i wkroczenia Armii Czerwonej na tereny Europy Środkowej i Wschodniej takie państwa, jak Polska, Czechosłowacja, Węgry, Rumunia, Bułgaria znalazły się w sferze wpływów sowieckich. W Azji wojna domowa w Chinach zakończyła się zwycięstwem komunistów i 1 października 1949 roku ich przywódca Mao Zedong (1893-1976) proklamował powstanie Chińskiej Republiki Ludowej. Jego przeciwnik Jiang Jieshi schronił się na Tajwanie, wspierany przez Stany Zjednoczone. Również na Półwyspie Koreańskim pojawiły się dwie strefy wpływów - w 1948 roku na południe od 38. równoleżnika powstała proamerykańska Republika Korei, na północ prosowiecka Koreańska Republika Ludowo-Demokratyczna. W czerwcu 1950 roku siły zbrojne KRLD rozpoczęły wojnę przeciw południu, która przyniosła jedynie miliony ofiar, a zakończyła się potwierdzeniem dotychczasowego podziału terytorialnego. Jednak wojna ta nabrała znaczenia międzynarodowego, gdyż Koreańczyków z północy wspierali tzw. ochotnicy chińscy, a tych z południa Amerykanie jako oficjalne wojska Organizacji Narodów Zjednoczonych. Podobnie było w Wietnamie, podzielonym na wspierany przez Francuzów i Zachód Wietnam Południowy i mający poparcie ZSRS oraz ChRL Wietnam Północny. Komuniści mieli też silne wpływy w Kambodży, Laosie, Birmie i Indonezji. Podział Azji stawał się coraz głębszy, a jego dalszą konsekwencją był także wyścig zbrojeń, nasilony po udanej próbie z radziecką bronią atomową we wrześniu 1949 roku?

Taka sytuacja miała naturalny wpływ na politykę Waszyngtonu i władz okupacyjnych wobec Tokio. Po pierwszych latach głębokich reform dotyczących demokratyzacji, demilitaryzacji i decentralizacji, realizowanych intensywnie od początku okupacji, w 1949 roku wprowadzono tzw. kurs zwrotny - Japonia miała odtąd stopniowo przyjąć rolę sojusznika Ameryki, a dzięki położeniu geograficznemu stać się też przyczółkiem antykomunistycznym podczas nasilającej się zimnej wojny. Waszyngton zwiększył pomoc gospodarczą dla Japonii, następnie inwestycje w celu odbudowy jej gospodarki, a po wybuchu wojny w Korei także potencjał obronny.

Po wojnie Polska, zgodnie z decyzjami trzech głównych przywódców sił alianckich: Wielkiej Brytanii, Stanów Zjednoczonych i Związku Sowieckiego, które zapadły głównie na konferencji w Jałcie (4-11 lutego 1945 r.), znalazła się w sferze wpływów Wschodu, całkowicie zależna od ZSRS. Zależność ta dotyczyła naturalnie

6 Na temat okupacji zob.: E. Pałasz-Rutkowska, K. Starecka, Japonia, Warszawa 2004, s. $190-218$.

7 Na temat sytuacji w Azji zob.: Zarys dziejów Afryki i Azji 1869-1996. Historia konfliktów, red. A. Bartnicki, Warszawa 1996, s. 227-235, 246-269.

8 E. Pałasz-Rutkowska, K. Starecka, Japonia, s. 208-218. 
także polskiej polityki zagranicznej, w tym również polityki wobec Japonii. Dlatego generalnie Polska, tak jak ZSRS i inne państwa bloku wschodniego, sprzeciwiła się szybkiemu podpisaniu traktatów pokojowych z państwami pokonanymi w czasie wojny z powodu konieczności uwzględnienia interesów zwycięzców, w tym także odszkodowań. Uważano, że kwestią traktatu powinny się zająć te same cztery państwa, które opracowały Deklaracje poczdamska, czyli Stany Zjednoczone, Wielka Brytania, ZSRS i Chiny ${ }^{9}$. Z dokumentów polskiego MSZ wynika jednak, że przedstawiciele ministerstwa uważali, iż trzeba zastanowić się również nad miejscem Polski w stosunkach z Japonią. 12 kwietnia 1947 roku naczelnik Wydziału Wschodniego Janusz Makarczyk (1901-1960) tak pisał do Tadeusza Chromeckiego (1904-1956?), wicedyrektora Departamentu Politycznego:

Nie wydaje się, aby specjalne akcentowanie stanu wojny pomiędzy Polską a Japonią było celowe; wydaje się wątpliwym, abyśmy mieli specjalnie duży głos w sprawie traktatu pokojowego z Japonią oraz ażeby były tytuły prawne do żądania odszkodowań. W tym stanie rzeczy należy zastanowić się nad sposobem naszej reprezentacji w Japonii, zważywszy, że Belgia, która była w analogicznej prawnej sytuacji, jak i my, ma w Tokio konsulat. Japonia, którą USA chciałyby jak najszybciej wprowadzić na arenę międzynarodową, ma odegrać rolę satelity o nastawieniu antyradzieckim $[\ldots]$

Aby uzyskać właściwy wgląd w bieg ważnych wydarzeń politycznych na całym Dalekim Wschodzie i aby móc należycie zorientować się, jakie korzyści ekonomiczne wyciągnąć może Polska z nowej sytuacji w Japonii, Rząd Polski winien mieć swą samodzielną placówkę obserwacyjną w Tokio, gdyż wiadomości uzyskiwane dotychczas za pośrednictwem środków masowej informacji i propagandy nie stanowią dostatecznej podstawy do wyciągania należnych wniosków politycznych ${ }^{10}$.

$\mathrm{Na}$ marginesie pisma minister spraw zagranicznych Zygmunt Modzelewski (1900-1954) napisał jednak, że uważa projekt stworzenia placówki za przedwczesny.

W następnych miesiącach 1947 roku, jak wynika z dokumentów polskiego Archiwum Ministerstwa Spraw Zagranicznych, Makarczyk nadal informował swoich zwierzchników o sytuacji w Japonii, o roli Stanów Zjednoczonych w jej odbudowie, a także o przygotowaniach głównych państw alianckich do zawarcia traktatu pokojowego $^{11} .2$ czerwca wyjaśniał, że Wielka Brytania dąży do tego, by zamiast przedstawicieli 4 czy 5 mocarstw w rokowaniach wzięło udział 11 reprezentantów państw walczących przeciw Japonii, co ,jest próbą zmajoryzowania Rosji”. 4 i 7 czerwca scharakteryzował pokrótce nowy, a uznany przez niego za „centrowy” gabinet, na którego czele 27 maja stanął socjalista oraz chrześcijanin Katayama Tetsu (18871987), i omówił jego najważniejsze problemy.

9 Historia dyplomacji polskiej, t. 6: 1944/1945-1989, red. W. Materski, W. Michowicz, Warszawa 2010, s. 421-422.

10 Dep. Polityczny, Wydz. Wschodni, Japonia 08. Org. stosunków dyplomatycznych. Notatka Wydziału dot. stosunków polsko-japońskich z propozycja utworzenia placówki w Tokio, 1947, zespół 6, teczka 1535, wiązka 97, s. 1-2, Archiwum Ministerstwa Spraw Zagranicznych, Warszawa (dalej jako: AMSZ).

11 AMSZ, Dep. Polityczny, Wydz. Wschodni, Japonia 2421. Notatki polityczne, 1947, zespół 6, teczka 1536, wiązka 97, s. 1, 6, 7 . 
W kolejnym piśmie z 10 czerwca Makarczyk poruszył problem polityki MacArthura wobec rozbrojenia Japonii, uznając, że jest ona silnie związana z polityką wobec Związku Sowieckiego. „Ameryka nie nalega na całkowite rozbrojenie Japonii, uważając ją za przyszłego wasala-sprzymierzeńca przy ewentualnej rozgrywce z ZSRR" ${ }^{2}$. We wrześniu natomiast pisał o znaczeniu Japonii dla interesów gospodarczych Stanów, co mogło niepokoić blok wschodni. Należy dodać, że w tym mniej więcej czasie, jesienią 1947 roku, Ministerstwo Spraw Zagranicznych oraz Ministerstwo Przemysłu i Handlu w Warszawie rozważały możliwość nawiązania kontaktów handlowych z Japonią. Z taką propozycją na wiosnę tego roku zwróciły się do władz polskich Ambasada Amerykańska w Warszawie i Izba Handlowa w Osace ${ }^{13}$. Choć część urzędników polskich była zainteresowana taką wymianą, a szczególnie importem z Japonii, do oficjalnego porozumienia w tej kwestii nie doszło.

Nasilanie się zimnej wojny i „,kurs zwrotny” wobec Japonii wpłynęły na przyśpieszenie prac nad traktatem pokojowym. Ważną kwestią w nowej sytuacji międzynarodowej stał się system bezpieczeństwa w tym regionie Azji, chroniący nie tylko przed możliwością odrodzenia się japońskiego militaryzmu, ale teraz przede wszystkim przed ekspansją komunizmu. A to wiązało się z możliwością utrzymania na terenie Japonii amerykańskich baz wojskowych (głównie na Okinawie) po zakończeniu okupacji. Z propozycją utrzymania baz po zawarciu pokoju wystąpił nawet premier Yoshida Shigeru $(1878-1967)^{14}$.

Prace nad podpisaniem traktatu nabrały tempa po wybuchy wojny na Półwyspie Koreańskim. 26 października 1950 roku John Foster Dulles (1888-1959), pełnomocnik Departamentu Stanu w tej sprawie (od 1953 r. sekretarz stanu), przekazal Jakubowi Malikowi (1906-1980), przedstawicielowi ZSRS w Organizacji Narodów Zjednoczonych, memorandum zawierające warunki traktatu pokojowego ${ }^{15}$. Moskwa odrzuciła je w połowie roku następnego, uznając, że niewskazane są odrębne rozmowy z Waszyngtonem. W tej sytuacji Amerykanie zaczęli brać pod uwagę możliwość zakończenia okupacji Japonii bez udziału państw bloku wschodniego i 12 lipca opublikowali propozycję traktatu pokojowego, opracowaną wspólnie z Wielką Brytanią. Tydzień później oba państwa ogłosiły, że konferencja pokojowa odbędzie się w San Francisco, a zaproszeni zostaną wszyscy zainteresowani, także Japonia. Ostatecznie udział potwierdziły 52 państwa, w tym ZSRS, Polska i Czechosłowacja. Na czele delegacji sowieckiej stanął wiceminister spraw zagranicznych Andriej Gromyko (1909-1989). Do San Francisco nie przyjechali przedstawiciele Indii, Birmy i Jugosławii, nie zaproszono natomiast Chińskiej Republiki Ludowej i Republiki Chińskiej (Tajwan), Demokratycznej Republiki Wietnamu oraz Mongolskiej Republiki Ludowej.

12 Ibidem, s. 8.

13 AMSZ, Dep. Polityczny, Wydz. Wschodni, Japonia 25. Stosunki gospodarcze RP. Propozycje nawiqzania stosunków handlowych z Japonia, 1947, zespół 6, teczka 1537, wiązka 97, s. 1-8.

14 E. Haliżak, Stosunki międzynarodowe w regionie Azji i Pacyfiku, Warszawa 1999, s. 150-154; por.: E. Pałasz-Rutkowska, K. Starecka, Japonia, s. 218-219.

15 Historia dyplomacji..., s. 421. 
Polska przyjęła zaproszenie dopiero pod koniec sierpnia. Pierwsza jego wersja, którą 20 lipca przekazał ministrowi spraw zagranicznych Stanisławowi Skrzeszewskiemu (1901-1978) ambasador Stanów Zjednoczonych w Warszawie Joseph Flack (1894-1955), została bowiem odrzucona ${ }^{16}$. Uznano, że nie spełnia ona warunków, gdyż w nocie nie zamieszczono ważnych fragmentów dotyczących traktatu. W skład delegacji polskiej weszli: wiceminister spraw zagranicznych Stefan Wierbłowski (1904-1977), ambasador Polski w Waszyngtonie Józef Winiewicz (1905-1984) i dyrektor Departamentu Prawno-Traktatowego MSZ Manfred Lachs (1914-1993). Strona amerykańska, akceptując to, zaznaczyła, że celem konferencji jest podpisanie traktatu, a nie dyskusja nad jego treścią, gdyż zainteresowane państwa robily to od września 1950 do sierpnia roku następnego.

Konferencja w San Francisco trwała od 4 do 8 września 1951 roku, a zakończyła się podpisaniem traktatu pokojowego przez 49 państw, bez ZSRS, Polski i Czechosłowacji ${ }^{17}$. W traktacie uwzględniono główne kwestie przynależności terytorialnej ziem okupowanych przez Japonię do 1945 roku. Japonia m.in. uznała niepodległość Korei, którą anektowała w 1910 roku, zrzekła się roszczeń do Formozy (Tajwan) i Wysp Rybackich (Peskadory), przyznanych jej po wygranej wojnie z Chinami w roku 1895. Zrzekła się także, co obiecano ZSRS w Jałcie ${ }^{18}$, południowego Sachalinu, który Rosja przekazała Japonii po przegranej wojnie w 1905 roku, oraz Wysp Kurylskich. Ta decyzja stanie się wkrótce powodem trwającego do dziś sporu terytorialnego. Zarówno w San Francisco, jak i w Jałcie nie sprecyzowano bowiem, jakie wyspy należą do Kurylów. Japończycy uważają, że Etorofu, Kunashiri, Shikotan i Habomai (tzw. Terytorium Północne), położone najbliżej Hokkaido, historycznie należą do Japonii ${ }^{19}$.

Poza tym w traktacie zobowiązano Tokio do wypłacenia odszkodowań wojennych, ale w wysokości niezagrażającej odbudowie gospodarczej kraju. Zaznaczono też, że Japonia jako suwerenne państwo ma prawo do obrony, a że została rozbrojona, ma prawo podpisywać układy o bezpieczeństwie zbiorowym. Zapowiedziano również, że choć oddziały okupacyjne mają się wycofać z Wysp Japońskich w ciągu $90 \mathrm{dni}$, to istnieje możliwość stacjonowania tu wojsk obcych na podstawie dwulub wielostronnych układów z Japonią. 8 września Japonia i Ameryka podpisały traktat o bezpieczeństwie, w którym godzono się m.in. na rozmieszczenie na terenie Japonii i wokół niej lądowych, powietrznych i morskich sił zbrojnych Stanów

16 Ibidem.

17 Traktat pokoju z Japonia zob.: Prawo międzynarodowe i historia dyplomatyczna. Wybór dokumentów, oprac. L. Gelberg, t. 3, Warszawa 1960, s. 455-465; wersja angielska: http://www.ioc.u-tokyo. ac.jp/ worldjpn/documents/texts/docs/19510908.T1E.html [dostęp: 10.01.2017].

18 ZdPISM, Uktad jattański, 1951, nr 9-10, dok. 128, s. 1537-1539.

19 Gdy po raz pierwszy ustalono granicę pomiędzy Japonią a Rosją, uznano, że będzie ona przebiegać pomiędzy wyspami Etorofu (ros. Iturup) a Uruppu (ros. Urup), wyspą należącą do Kurylów, zob.: Nihonkoku Roshiakoku tsūshō jōyaku (Traktat o przyjaźni między Japonią a Rosją) [w:] Nihon gaikō nenpyō narabi ni shuyō na bunsho 1840-1945 (Tablice chronologiczne i najważniejsze dokumenty dyplomacji japońskiej), t. 1, Tōkyō 1976, s. 5, 6. 
Zjednoczonych ${ }^{20}$. Siły te mogły być użyte jedynie dla utrzymania pokoju i bezpieczeństwa na Dalekim Wschodzie oraz dla zabezpieczenia Japonii przed zbrojnym atakiem z zewnątrz. Zapisano też, że Japonia, bez porozumienia ze Stanami, nie udzieli zgody żadnemu innemu państwu na powstanie nowych baz na jej terenie.

Podczas konferencji przedstawiciel Polski Wierbłowski wystąpił trzy razy, a ton jego wypowiedzi był typowy dla ówczesnej propagandy radzieckiej i polityki zimnowojennej przyjętej przez blok wschodni. Zdawał się także nie pamiętać o informacji przekazanej delegacji przed wyjazdem przez Amerykanów, a dotyczącej niemożności dyskusji nad traktatem. 5 września Wierbłowski zabrał głos dwukrotnie na temat regulaminu konferencji ${ }^{21}$. Mówił m.in. o konieczności powołania komisji regulaminowej, która powinna ustalić zakres działania i uprawnienia konferencji, jej porządek dzienny oraz regulamin. W drugim przemówieniu powrócił do zasad procedury, uważając, że projekt regulaminu przygotowany przez delegacje Stanów Zjednoczonych i Wielkiej Brytanii uszczupla suwerenność innych państw ${ }^{22}$. Tekst traktatu został bowiem ustalony wcześniej i rozesłany uczestnikom, a wystąpienia przedstawicieli poszczególnych delegacji ograniczono do jednego, nietrwającego dłużej niż godzinę. Polak uznał, że uczestnicy zostali praktycznie pozbawieni możliwości negocjacji. Po raz trzeci Wierbłowski wystąpił 7 września ${ }^{23}$. Podkreślając znaczenie ZSRS w doprowadzeniu do zakończenia wojny i powołując się na postanowienia z Jałty i Poczdamu, uznał, że sprawą traktatu pokojowego z Japonią od samego początku powinna zająć się Rada Ministrów Spraw Zagranicznych, czyli także przedstawiciele Moskwy. Ponadto za ,jeden z najbardziej bezwstydnych aktów bezprawia w stosunkach międzynarodowych" uznał niedopuszczenie ChRL do współdecydowania o trakta$\mathrm{cie}^{24}$. Poruszył też kwestię spraw terytorialnych, twierdząc, że Japonia musi uznać suwerenność ZSRS nad Kurylami i Sachalinem, co było odpowiedzią na wystąpienie $\mathrm{z}$ dnia poprzedniego premiera Japonii, Yoshidy Shigeru, który aprobował traktat, ale zakwestionował przyznanie Wysp Kurylskich i południowego Sachalinu Sowietom. Co ciekawe, Wierbłowski był natomiast przeciwny przekazaniu wysp Bonin (Ogasawara) i Riukiu (Okinawa) pod powiernictwo ONZ, gdyż według niego dla suwerennej Japonii oznaczało to „zredukowanie jej do kraju kolonialnego” i pozostanie „pod trwałym władaniem Stanów Zjednoczonych", które dokonują w ten sposób aneksji. Dodam, że wyspy znalazły się pod okupacją amerykańską, a powróciły w granice japońskie dopiero w 1968 i 1972 roku. Polak poparł też wniosek Moskwy zabraniający Japonii zawierania ,jakichkolwiek przymierzy wojskowych i wchodzenia w koalicje

20 ZdPISM, Traktat o bezpieczeństwie między Stanami Zjednoczonymi Ameryki a Japonia, 1951, nr 9-10, dok. 161, s. 1980-1983; por.: Security Treaty Between Japan and the United States of America, Database of Japanese Politics and International Relations Institute of Oriental Culture, University of Tokyo, http://www.ioc.u-tokyo.ac.jp/ worldjpn/documents/texts/docs/19510908.T2E.html [dostęp: 10.01.2017].

21 ZdPISM, Przemówienie przedstawiciela Rzeczypospolitej Polskiej wiceministra spraw zagranicznych Stefana Wierbłowskiego w sprawie regulaminu konferencji, 1951, nr 9/10, dok. 151 i 154 , s. 1806-1811, s. 1827-1837.

22 Ibidem, dok. 154, s. 1830.

23 ZdPISM, Przemówienie przedstawiciela Rzeczypospolitej Polskiej wiceministra spraw zagranicznych Stefana Wierbłowskiego, 1951, nr 9/10, dok. 157, s. 1936-1948.

24 Ibidem, s. 1939. 
przeciwko jakiemukolwiek państwu, którego siły zbrojne uczestniczyły w ostatniej wojnie przeciwko Japonii" 25 .

Ostatecznie 8 września delegacja PRL odmówiła podpisania traktatu pokojowego z Japonią. Na konferencji prasowej Wierbłowski oświadczył, że Polska nie może zgodzić się na przyjęty w San Francisco „separatystyczny” traktat, w którym nie uwzględniono „poprawek wniesionych przez filar zwycięstwa nad faszyzmem - Związek Radziecki”"26. Uznał też, że podpisany dokument będzie „krokiem w kierunku zwiększenia napięcia międzynarodowego". Dzień później Wierbłowski udzielił wywiadu korespondentowi Polskiej Agencji Prasowej ${ }^{27}$. Mówił w nim, że traktat przyczynił się do

[...] odrodzenia militaryzmu japońskiego, [...] do przekreślenia niepodległości i suwerenności Japonii w rezultacie utrzymania w Japonii amerykańskich wojsk okupacyjnych, [...] do przymusowego włączenia Japonii do agresywnej koalicji wojennej, wymierzonej przeciw państwom, które brały udział w wojnie z Japonią, [...] do pogwałcenia istniejących umów i zobowiązań międzynarodowych w odniesieniu do problemów terytorialnych, jakie wynikły z wojny przeciw Japonii,

a także do „odbudowy pokonanego militaryzmu w służbie imperializmu amerykańskiego"28. Jednoznacznie więc strona polska, podobnie jak ZSRS i Czechosłowacja, wypowiedziała się przeciwko traktatowi z San Francisco.

$\mathrm{Z}$ tego powodu następne lata nie przyniosły wyraźnych zmian w polityce Polski wobec Japonii, choć wielu polityków powracało do tematu, uznając, że nie ma między naszymi krajami żadnych specjalnych zadrażnień2 ${ }^{29}$. Sytuacja zaczęła się zmieniać po śmierci Stalina w 1953 roku, po której swój stosunek do Japonii złagodziła Moskwa. Doszło do rozmów na temat powrotu pozostałych japońskich jeńców wojennych i osób cywilnych, przetrzymywanych nadal w tragicznych warunkach w obozach, m.in. na Syberii ${ }^{30}$. Dzięki temu z większym nasileniem prowadzono rozmowy na temat przywrócenia stosunków dyplomatycznych.

Nastawienie Moskwy do Japonii obserwowano w Warszawie z dużym zainteresowaniem. Jednak zakończenie stanu wojny między Polską a Japonią na podstawie traktatu pokojowego było nadal niemożliwe ze względów zarówno politycznych, jak i prawnych. Polska, wraz z ZSRS i Czechosłowacją, nie podpisała traktatu z San Francisco, gdyż uznała go za separatystyczny i zmiana takiego nastawienia wymagałaby wspólnej decyzji bloku wschodniego. A w artykule 26 traktatu z San Francisco

25 Ibidem, s. 1945, 1947.

26 ZdPISM, Oświadczenie przedstawiciela Rzeczypospolitej Polskiej wiceministra spraw zagranicznych Stefana Wierbłowskiego na konferencji prasowej po zamknięciu konferencji pokojowej w San Francisco, 1951, nr 9/10, dok. 159, s. 1969-1971.

27 ZdPISM, Wywiad korespondenta Polskiej Agencji Prasowej z przedstawicielem Rzeczypospolitej Polskiej wiceministrem spraw zagranicznych Stefanem Wierbłowskim, 1951, nr 9/10, dok. 160, s. $1972-1979$.

28 Ibidem, s. 1973, 1974.

29 Historia dyplomacji..., s. 423.

30 Zob. szczegóły w: T. Kurihara, Shiberia horyū - mikan no higeki (Jeńcy na Syberii - niekończąca się tragedia), Tōkyō 2009. 
zapisano, że zawarcie przez Japonię dwustronnego traktatu pokoju z krajem, który nie podpisał dokumentu z 1951 roku, możliwe jest tylko na tych samych lub zasadniczo tych samych warunkach. Dodano tam, że „ten obowiązek Japonii wygaśnie po upływie lat trzech od chwili pierwszego wejścia w życie niniejszego traktatu" ${ }^{11}$, czyli w kwietniu 1955 roku.

Kolejne materiały dyplomatyczne na temat stosunków z Japonią pojawiają się w 1954 roku. W polskim MSZ uważano, że choć podpisanie traktatu z Japonią jest w ówczesnych warunkach nadal trudne, istnieje możliwość nawiązania stosunków dyplomatycznych bez formalnego zakończenia stanu wojny. Tak bowiem stało się np. z Włochami i Finlandią - Polska utrzymywała stosunki z tymi państwami, zanim podpisano traktaty pokojowe ${ }^{32}$. Rozmowy w sprawie nawiązania stosunków rozpoczął w kwietniu 1954 roku Takahashi, drugi radca ambasady Japonii w Paryżu. Prowadził je początkowo z Kłosem, attaché prasowym ambasady Polski tamże, a następnie, od maja, z chargé d'affaires Przemysławem Ogrodzińskim (1918-1980), który przekazał gotowość rządu PRL do wznowienia stosunków na wniosek strony japońskiej, ale podkreślał, że umowa taka nie załatwi spraw spornych między dwoma krajami, czyli kwestii traktatu z San Francisco ${ }^{33}$. Godzono się także na ustanowienie ambasad w stolicach obu krajów. Polskie MSZ uzyskało zgodę Moskwy na takie działania 22 kwietnia 1954 roku - ambasador ZSRS w Warszawie, Nikołaj Michajłow (1906-1982), powiedział ministrowi Skrzeszewskiemu, że nie widzi przeszkód w negocjacjach z Japonią, ale wspomniał także o konieczności uświadomienia jej, że otwarta jest nadal kwestia traktatu pokojowego. Poparł sprawę podpisania polsko-japońskich umów handlowych ${ }^{34}$.

W następnych latach sprawa wznowienia stosunków oficjalnych nabrała tempa. Dyrektor Departamentu Prawno-Traktatowego MSZ Manfred Lachs w tajnej notatce do wiceministra Mariana Naszkowskiego (1912-1996) z 14 stycznia 1955 roku podtrzymywał opinię, że ze względu na postawę delegacji PRL w San Francisco zawarcie traktatu pokojowego jest na razie niemożliwe. Ale pisał także, że:

[...] szybkie nawiązanie między Japonią a Polską takich stosunków, jakie istnieją między suwerennymi państwami, włącznie ze stosunkami dyplomatycznymi, odpowiada interesom obu krajów i może przyczynić się do międzynarodowego pokoju. [...] Dlatego też możliwe jest nawiązanie stosunków, bez uregulowania - w tej chwili - sprawy traktatu pokoju, jak i formalnego zakończenia wojny. Ułatwia to z naszej strony brak konkretnych problemów majątkowych i finansowych $\mathrm{z}$ Japonią, a także norm prawnych $\mathrm{z}$ tym związanych /mamy jedynie sprawę urządzenia Ambasady w Tokio/35.

Pozytywne nastawienie strony polskiej do sprawy nawiązania stosunków oficjalnych z Japonią przedstawia też w korespondencji z ministrem spraw zagranicznych Shigemitsu Mamoru (1887-1957) ambasador Japonii w Paryżu Nishimura Kumao

31 Prawo międzynarodowe i historia dyplomatyczna..., s. 465.

32 AMSZ, Departament V, Wydział III, Japonia 08. Nawiąywanie stosunków dyplomatycznych z Japonia, 1954-1957, zespół 12, teczka 367, wiązka 15, s. 1.

33 Ibidem, s. 7.

34 Ibidem, s. 2.

35 Ibidem, s. 4-8. 
$(1899-1980)^{36}$. W depeszy z 21 stycznia 1955 roku pisze, że Stanisław Gajewski (1912-1995), ambasador Polski we Francji, przyjął pismo rządu japońskiego w tej sprawie i że możliwe jest, według niego, nawiązanie dwustronnych stosunków, a sprawa uporządkowania stosunków Tokio - Moskwa jest tu bez związku i nie wpłynie na stosunki Warszawa - Moskwa ${ }^{37}$. Potwierdził niezmienny nadal stosunek Polski do traktatu z San Francisco. Dalej ambasador Nishimura pisał, że niezależnie od nawiązania stosunków dyplomatycznych strona polska uważa, iż konieczne jest także podpisanie umów handlowych i kulturalnych. Radził, by treść układu o przywróceniu stosunków międzypaństwowych była wspólnie opracowana za zgodą rządów obu państw i wspólnie ogłoszona. Informował, że projekt umowy, omówiony w Paryżu, zostanie przedstawiony do dalszej akceptacji ${ }^{38}$. Nishimura dodał też, że ambasador Gajewski podkreślał w rozmowie tradycyjnie przyjazne nastawienie Polaków do Japończyków. Kolejną rozmowę z ambasadorem Gajewskim Nishimura omówił w depeszy do ministra Shigemitsu z 10 czerwca 1955 roku. Dotyczyła stosunku państw komunistycznych, a przede wszystkim ZSRS do różnych problemów europejskich, co miało duże znaczenie dla Japoniii ${ }^{39}$. Dodam, że o działaniach Nishimury wspomniała także japońska prasa ${ }^{40}$.

Ważne dla dalszego przebiegu rozmów Polaków z Japończykami było exposé na temat polityki zagranicznej Polski prezesa Rady Ministrów Józefa Cyrankiewicza (1911-1989), wygłoszone w Sejmie 16 marca 1955 roku $^{41}$. Powiedział tam: ,jesteśmy za unormowaniem naszych stosunków z daleką Japonią", co z pewnością było możliwe dzięki ówczesnej polityce Moskwy wobec Tokio, zmierzającej do uregulowania stosunków dwustronnych. Oficjalne negocjacje Rosjanie prowadzili z Japończykami od czerwca do września 1955 roku i na początku roku następnego w Londynie ${ }^{42}$. Premier Hatoyama Ichirō (1883-1959), choć dążył do zakończenia stanu wojny z ZSRS, naciskany przez polityków swojej rządzącej Partii Liberalno-Demokratycznej ${ }^{43}$ postawił twarde warunki. Zawarcie traktatu pokojowego uzależnił m.in. od zwrotu Japonii czterech spornych wysp, uznanych przez ZSRS za część Wysp Kurylskich. Nikita Chruszczow (1894-1971), I sekretarz Komitetu Centralnego Komunistycznej

${ }^{36}$ GGS, Pōrando to no kokkō kaifuku ni kansuru ken (Sprawa wznowienia stosunków państwowych z Polską) [w:] A'1.3.3.5-1 (Nihon Pōrandokan gaikō kankei zasshū. Kokkō kaifuku kōshō kankei; Dokumenty różne na temat dyplomacji między Japonią a Polską. Negocjacje dot. wznowienia stosunków państwowych), cz. 1, s. 15-35.

37 Ibidem, s. 33-35.

38 Projekt umowy: ibidem, s. 38-40.

39 GGS, Ōshū shomondai ni taisuru kyōsan'en no tachiba ni tsuki Pōrando taishi no danwa (Rozmowa $\mathrm{z}$ ambasadorem Polski na temat postawy bloku komunistycznego wobec różnych problemów europejskich), A'1.3.3.5-1, cz. 1, s. 68-73.

40 Zob. np. „,Tainichi fukkō” yobikake. Pōrando, Nishimura taishi tsūji (Wezwanie do „wznowienia stosunków z Japonią”. Polska, za pośrednictwem ambasadora Nishimury), „Yomiuri Shinbun” 1954, 27.12 .

41 O polityce zagranicznej Rząu Polskiej Rzeczypospolitej Ludowej. Exposé tow. Józefa Cyrankiewicza, „Trybuna Ludu” 1955, 16.03, s. 3-5.

42 E. Pałasz-Rutkowska, K. Starecka, Japonia, s. 245-247.

43 Powstała z inicjatywy Hatoyamy w 1955 r. po połączeniu Partii Liberalnej i Japońskiej Partii Demokratycznej; rządziła bez przerwy do 1993 r. Stałą opozycją była Socjalistyczna Partia Japonii. 
Partii Związku Sowieckiego, chciał jak najszybciej przywrócić stosunki dwustronne z Japonią, uważając, że przez Stalina tylko Amerykanie czerpią korzyści ze współpracy z Japończykami. Ale nie zmieniono zdania na temat spornych wysp. Podczas kolejnych rozmów, prowadzonych latem 1956 roku w Moskwie, minister Shigemitsu był już gotów na ustępstwa i na przyjęcie tylko dwóch małych wysp położonych u wybrzeży Hokkaido, ale taka decyzja nie podobała się Stanom Zjednoczonym, które powołując się na wspomniany wyżej artykuł 26 traktatu z San Francisco, zapowiedziały, że jeśli Etorofu i Kunashiri zostaną w granicach ZSRS, one nie zwrócą okupowanych wysp Riukiu i Bonin. Ostatecznie Hatoyama zgodził się przyjąć „formułę Adenauera" i 19 października 1956 roku w Moskwie, oddzieliwszy normalizację stosunków od traktatu, Japończycy podpisali z Rosjanami deklarację o zakończeniu stanu wojny i przywróceniu stosunków dyplomatycznych ${ }^{44}$. Moskwa zgodziła się także na uwolnienie jeńców i przystąpienie do rozmów na temat współpracy gospodarczej.

Od drugiej połowy 1955 roku zaczęła się rozwijać współpraca między Polską a Japonią. Na przykład w dniach 22-25 września 1955 roku na zaproszenie Sejmu PRL i Polskiej Grupy Międzyparlamentarnej przebywała w Polsce po raz pierwszy delegacja parlamentarzystów japońskich, na której czele stanął socjalista Nomizo Masaru (1898-1978). Na konferencji prasowej w Warszawie on także podkreślił konieczność normalizacji stosunków ${ }^{45}$. Dzięki działaniom wybitnego japonisty, profesora Wiesława Kotańskiego (1915-2005) przy Katedrze Sinologii na Uniwersytecie Warszawskim rozwijała się specjalizacja japonistyczna ${ }^{46}$. Polska delegacja wzięła udział w Międzynarodowej Konferencji w sprawie Zakazu Stosowania Broni Jądrowej, zorganizowanej w Hirosimie. Wizyta delegacji Komitetu Łączności Międzynarodowej Japońskich Związków Zawodowych Pracowników Budowlanych i Drzewnych w maju 1956 roku zapoczątkowała późniejsze kontakty związkowców polskich i japońskich. 28 września 1956 roku powstało w Tokio Towarzystwo Japonia - Polska (Nihon Pōrando Kyōkai; The Japan Poland Society) ${ }^{47}$. W spotkaniu inauguracyjnym w budynku japońskiego parlamentu udział wzięli m.in. Mori Motojirō (1907-1999), Nomizo Masaru, Sakō Itoko, wdowa po Shūichim (1887-1949), pierwszym i ostatnim przed wojną ambasadorze Japonii w Polsce, Hara Chieko (1914-2001), pierwsza pianistka japońska, która wzięła udział w Konkursie Chopinowskim (1937). Wszyscy mieli kontakty z Polską, byli w Polsce przed lub po wojnie. Głównym organizatorem Towarzystwa był Mori, członek izby wyższej parlamentu, przed wojną korespondent Agencji Prasowej Dōmei w Polsce, który wziął na siebie obowiązki sekretarza generalnego do czasów wyborów przewodniczącego ${ }^{48}$.

44 ZdPISM, Wspólna deklaracja Zwiazku Radzieckiego i Japonii oraz protokót o rozwoju handlu i wzajemnym przyznaniu klauzuli największego uprzywilejowania, 1956, nr 10, dok. 308, s. 1584-1591.

45 Historia dyplomacji.., s. 425.

46 E. Pałasz-Rutkowska, K. Starecka, Kalendarium kontaktów polsko-japońskich, „Japonica” 2000, nr 12, s. 224. Od 1957 r. jako Zakład Japonistyki.

47 Zob. List od Moriego Motojirō do ministra spraw zagranicznych PRL: AMSZ, Departament V, Wydział III, Japonia 568. Pismo informujace o powstaniu Towarzystwa Japonia - Polska, 1956, zespół 12, teczka 364, wiązka 15 , s. 1-2.

48 Dokumenty różne ze zbiorów córki Moriego, Mariko (Archiwum prywatne Mori Mariko, Tokio). Towarzystwo zostało rozwiązane w 1961 r., odrodziło się dzięki staraniom Moriego w 1975 r. 
Rozmowy dyplomatyczne przedstawicieli Polski i Japonii prowadzono z większym nasileniem w roku 1956, i to nie tylko w Warszawie czy w Tokio. W marcu, w Sztokholmie, tamtejszy poseł japoński Ōe Akira rozmawiał z posłem PRL Józefem Koszutskim (1906-1979), wyrażając pogląd, że stosunki zostaną wkrótce nawiąza$\mathrm{ne}^{49}$. Podobnego zdania był ambasador Japonii w Hadze, Okamoto Suemasa (18921967), który w dniach 1-4 maja 1956 roku przebywał w Polsce wraz z małżonką i attaché ambasady Yatabe Atsuhiko (ur. 1929) w celu podpisania protokołu haskiego do konwencji warszawskiej dotyczącej przewozu lotniczego. Podczas spotkania w MSZ, podobnie jak wcześniej podczas rozmowy z posłem PRL w Hadze, Tadeuszem Findzińskim (1911-1987), stwierdził on m.in., że wkrótce po uregulowaniu stosunków z ZSRS można będzie nawiązać stosunki Japonii z Polską ${ }^{50}$. Oświadczył wówczas również, że „nie mieliśmy żadnych sporów, byliśmy przyjaciółmi i możemy zostać nimi w przyszłości”51. Delegacja zwiedziła Warszawę, interesując się m.in. ambasadą Japonii przed wojną i kosztami utrzymania ewentualnej nowej placówki. Udała się także do Krakowa i Nowej Huty. W czasie wizyty w niemieckim obozie koncentracyjnym w Auschwitz ambasador Okamoto nawiązał do obozów na terenie ZSRS, w których nadal przebywali jeńcy japońscy. Zapytał, czy Polska nie mogłaby wpłynąć na swego wschodniego sąsiada, by jak najszybciej zlikwidował ten problem ${ }^{52}$. Nie uzyskał jednak wsparcia, gdyż Polacy nie byli upoważnieni do zabierania głosu w tej sprawie i prawdopodobnie niewiele o niej wiedzieli.

Sprawa stosunków Japonii z państwami Europy Wschodniej w latach 1939-1956, w tym możliwości odnowienia oficjalnych kontaktów dyplomatycznych, została przedstawiona przez Departament Europy i Stanów Zjednoczonych japońskiego MSZ w dokumentach z 5 i 22 czerwca 1956 roku $^{53}$. Polska omawiana jest tu najdokładniej, przed Czechosłowacją, Rumunią, Bułgarią, Węgrami, Albanią i Jugosławią, co może oznaczać, że Japonii zależało na szybkim wznowieniu stosunków z Polską $\mathrm{z}$ racji bardzo dobrych kontaktów przed wojną.

Według dokumentów polskich już pod koniec sierpnia 1956 roku ambasador Japonii przy Organizacji Narodów Zjednoczonych, Kase Toshikazu (1903-2004), poinformował Henryka Bireckiego, ambasadora PRL tamże, że w najbliższych tygodniach będzie upoważniony przez MSZ do podjęcia rozmów na temat nawiązania stosunków ${ }^{54}$. Na początku października Kase zaproponował następcy Bireckiego, Jerzemu Michałowskiemu (1909-1993), rozpoczęcie rozmów bez konieczności czekania na podpisanie traktatu z ZSRS. 18 października Michałowski dostał oficjalne instrukcje swoich władz, które pokrywały się z tym, o czym pisano już dwa lata

49 Notatka z 24 X 1956 [w:] AMSZ, Departament V, Wydział III, Japonia 08..., s. 7.

50 AMSZ, Departament V, Wydział III, Japonia 074. Wizyta w Polsce japońskiego Ambasadora w Hadze S. Okamoto, zespół 12, teczka 362, wiązka 15, s. 1-7.

51 Ibidem, s. 6.

52 Ibidem, s. 5, 6.

53 GGS, Waga kuni to Tōō shokoku to no kankei (Związki naszego kraju z państwami Europy Wschodniej) i Tōō shokoku to no kokkō kaifuku mondai ni kansuru keii (Szczegóły dotyczące problemu wznowienia stosunków państwowych z państwami Europy Wschodniej), A’1.3.3.5-1, cz. 1, s. 81-94.

54 Notatka z 24 X $1956 \ldots$, s. 7. 
wcześniej. A mianowicie: Polska jest gotowa nawiązać stosunki dyplomatyczne; wymienione mają być deklaracje o zakończeniu stanu wojny bez przesądzania sprawy traktatu pokojowego; nastąpi wymiana przedstawicieli dyplomatycznych w stopniu ambasadorów oraz nawiązanie stosunków handlowych ${ }^{55}$.

Dokumenty na temat rozmów w Nowym Jorku znajdują się też w Archiwum Dyplomatycznym MSZ w Tokio. Kase pisał o tym szczegółowo w depeszach do ministra Shigemitsu, podkreślając m.in. pozytywne nastawienie przedstawiciela Polski $^{56}$. Relacjonował także przebieg rozmów z delegacjami z innych państw, m.in. Czechosłowacji i Węgier ${ }^{57}$. Omówienie tych wszystkich dokumentów wykracza poza ramy tej pracy, ale należy zaznaczyć, że wiele z nich pochodzi z grudnia 1956 roku, co niewątpliwie oznacza, że dążono już bardzo do finalizacji rozmów i podpisania oficjalnego porozumienia ${ }^{58}$. Pod koniec tego miesiąca pojawiły się pierwsze propozycje układu z Polską, kierowane początkowo do chargé d'affaires Japonii w Paryżu, Matsuiego Akiry, który omawiał to prawdopodobnie $\mathrm{z}$ ambasadorem PRL tamże ${ }^{59}$. Od stycznia 1957 roku depesze w tej sprawie wysyłał nadal ambasador Kase, adresowane od grudnia 1956 roku już do nowego ministra spraw zagranicznych Kishiego Nobusuke (1896-1987) ${ }^{60}$. Na początku lutego szczegółowo informował ministra o poprawkach, które za porozumieniem stron nanoszono w oficjalnej wersji układu w języku francuskim ${ }^{61}$.

$Z$ tajnej notatki dla wiceministra spraw zagranicznych Mariana Naszkowskiego, przygotowanej przez dyrektora Departamentu V Edwarda Słuczańskiego na początku 1957 roku, wynika, że kwestią sporną był artykuł 4 układu, który zgodnie z propozycją japońską miał brzmieć: „Polska i Japonia zrzekają się wzajemnie wszystkich roszczeń państwa lub jego organizacji względnie obywateli powstałych $\mathrm{w}$ czasie wojny między dwoma krajami" ${ }^{2}$. Początkowo strona polska, przede wszystkim Ministerstwo Finansów, była przeciwna zamieszczaniu tej klauzuli, ale ostatecznie, 8 lutego, Naszkowski, po uzyskaniu akceptacji MSZ, Ministerstwa Finansów i Ministerstwa Handlu Zagranicznego wysłał depeszę wraz z pełnym tekstem układu pomiędzy PRL a Japonią (zawierającym powyższy artykuł) do aprobaty prezesa Rady Ministrów, Józefa Cyrankiewicza ${ }^{63}$.

Tego samego dnia, 8 lutego 1957 roku, w Nowym Jorku ambasador Japonii przy Organizacji Narodów Zjednoczonych, Kase Toshikazu, oraz wiceminister spraw zagranicznych i przewodniczący delegacji polskiej na XI sesję Zgromadzenia Ogólnego ONZ, Józef Winiewicz (1905-1984), mając pełnomocnictwa od swoich

55 Ibidem, s. 7, 8 .

56 Zob. np. depesza z 22.10.1956, GGS, Pōrando no kokkō kaifuku mōshiire no ken (Sprawa propozycji wznowienia stosunków państwowych z Polską), A' 1.3.3.5-1, cz. 1, s. 95-97.

57 Ibidem, s. 110, 118-119, 120.

58 Ibidem, s. 109-128.

59 Ibidem, s. 128-139.

60 Ibidem, s. 144-150, 167-170, 177-182, 190-194.

61 Ibidem, s. 220-227.

62 AMSZ, Departament V, Wydział III, Japonia 08..., s. 15.

63 Ibidem, s. 18-20. 
zwierzchników, ministra Kishiego i premiera Cyrankiewicza ${ }^{64}$, podpisali Uktad o przywróceniu normalnych stosunków między Polska Rzeczpospolita Ludowa a Japonia (Nihonkoku to Pōrando Jinmin Kyōwakoku to no aida no kokkō kaifuku ni kansuru kyōtei $)^{65}$.

W artykule 1 ogłoszono, że z dniem wejścia w życie układu - co nastąpi z dniem wymiany dokumentów ratyfikacyjnych $\mathrm{w}$ Warszawie - zostanie zakończony stan wojny między obu państwami. W artykule 2 podano, że wznowione zostaną stosunki dyplomatyczne i nastąpi wymiana ambasadorów. Najdłuższy artykuł 3 dotyczył zobowiązania obu stron do kierowania się zasadami karty Narodów Zjednoczonych, czyli rozwiązywania sporów międzynarodowych na drodze pokojowej, bez użycia siły, oraz do nieingerowania w wewnętrzne sprawy drugiej strony. Przytoczony wyżej artykuł 4, w którym zrzekano się wszelkich roszczeń, uległ tylko drobnym poprawkom stylistycznym. W artykule 5 zapowiedziano przystąpienie do rokowań na temat stosunków gospodarczych. W ostatnim artykule 6 była mowa o ratyfikacji i podpisach.

We wspólnym komunikacie z 9 lutego podano:

Przywrócenie normalnych stosunków między Polską Rzeczpospolitą Ludową i Japonią było od dłuższego czasu sprawą wymagającą uregulowania między obu krajami. Rządy obu krajów, kierując się pragnieniem niezwłocznego uregulowania tego problemu, poleciły ambasadorowi PRL Jerzemu Michałowskiemu i ambasadorowi Japonii Kase Toshikazu, stałym przedstawicielom tych krajów w ONZ, aby podjęli w tym celu rokowania. W wyniku tych rokowań osiągnięto między obu rządami całkowite porozumienie [...]. Z chwilą wejścia tego układu w życie, Polska i Japonia zakończą istniejący między nimi stan wojny, wznowią stosunki dyplomatyczne i dokonają wymiany ambasadorów. Oba narody tym samym przywrócą swe tradycyjne stosunki współpracy i przyjaźni. Przyczyni się to nie tylko do pomyślności obu narodów, lecz także do utrwalenia pokoju na świecie przez złagodzenie napięcia międzynarodowego ${ }^{66}$.

Wymiana dokumentów ratyfikacyjnych nastąpiła 18 maja 1957 roku w budynku MSZ w Warszawie ${ }^{67}$. Stronę polską reprezentował minister spraw zagranicznych Adam Rapacki (1909-1970), a stronę japońską ambasador nadzwyczajny w misji specjalnej Sonoda Sunao (1913-1984) ${ }^{68}$. Minister Rapacki wyraził przekonanie, że od tego momentu otwiera się nowy rozdział w historii stosunków polsko-japońskich, w którym rozwijać się będą stosunki polityczne, gospodarcze i kulturalne. Ambasador Sonoda powiedział m.in.:

${ }^{64}$ GGS, A’ 1.3.3.5-1, cz. 1, s. 291 i 302.

${ }_{65}$ Oryginał w języku francuskim oraz wersja polska: Internetowa baza traktatowa MSZ, Warszawa, https://www.traktaty.msz.gov.pl/bap.php [dostęp: 20.01.2017]; por.: AMSZ, Departament V, Wydział III, Japonia 08..., s. 19-20; wersja japońska w: GGS, A'1.3.3.5-1, cz. 2, s. 19-22. Pisała o tym japońska prasa. Zarówno „Yomiuri Shinbun”, jak i „Asahi Shinbun” 9 lutego na pierwszej stronie zamieściły zdjęcia Kasego i Winiewicza, a sprawę podpisania układu omawiano tam już od początku stycznia.

66 Zob.: „Trybuna Ludu” 1957, 9.02, s. 1; „Yomiuri Shinbun” 1957, 9.02, s. 1; oficjalna wersja japońska: GGS, Nihonkoku oyobi Pōrando Jinmin Kyōwakoku to no aida no kokkō kaifuku ni kansuru kyōtei no chomei ni tsuite no kyōdō komyunike, A' 1.3.3.5-1, cz. 1, s. 289.

${ }^{67}$ Na temat przygotowań do ratyfikacji zob. dokumenty różne w: GGS, A’ 1.3.3.5-1, cz. 2, s. 17-66.

68 AMSZ, Departament V, Wydział III, Japonia 08..., s. 23. 
[...] nasze kraje były w przeszłości złączone więzami serdecznej przyjaźni, które zostały zerwane w okresie drugiej wojny światowej z wielką szkodą dla obu narodów [...]. Nasz naród i rząd [...] są przekonane, że przyjaźń nasza będzie się zacieśniać w interesie Japonii i Polski ${ }^{69}$.

Po ratyfikacji Sonoda został przyjęty przez I sekretarza Komitetu Centralnego Polskiej Zjednoczonej Partii Robotniczej Władysława Gomułkę (1905-1982) i prezesa Rady Ministrów Józefa Cyrankiewicza. Tego samego dnia Sonoda w depeszy do ministra Kishiego donosił, że ratyfikacja dokumentów przebiegła zgodnie z planem. Poinformował też swego zwierzchnika o spotkaniu z Gomułką i premierem ${ }^{70}$. Ponadto Sonodę przyjął na śniadaniu wiceminister spraw zagranicznych Winiewicz, a towarzyszyli mu wiceminister handlu zagranicznego Franciszek Modrzewski (1902-1985) i poseł na Sejm Jan Karol Wende (1910-1986). Japończyk wysłuchał także koncertu muzyki Chopina w Żelazowej Woli.

Wkrótce po podpisaniu układu obie strony rozpoczęły przygotowania do otwarcia swych placówek dyplomatycznych w Tokio i Warszawie oraz do wyboru kandydatów na ambasadorów. $Z$ dokumentów polskich wynika, że prace te zaczęto już 9 lutego $1957 \mathrm{roku}^{71}$. Przygotowaniem placówek zajęły się wydelegowane przez swych zwierzchników grupy robocze, a ich szefów zatwierdzono jako chargé d'affaires ad interim. Zostali nimi ze strony polskiej 14 sierpnia 1957 roku Jerzy Bryn (19161978), a ze strony japońskiej 15 grudnia tego roku Dōshō Hisashi ${ }^{72}$. Przygotowanie placówek i zebranie ich personelu nie było łatwe, dlatego wymaga dokładniejszego omówienia, co wykracza poza ramy tej pracy. Dodam tylko, że ostatecznie pierwszym ambasadorem PRL w Tokio został 25 listopada 1957 roku Tadeusz Żebrowski, a ambasadorem Japonii w Warszawie 31 grudnia Ōta Saburō (1905-? $)^{73}$. Żebrowski, działacz lewicowy i członek PZPR, pracował m.in. w Departamencie III MSZ, ale „miał przez dłuższy okres czasu przerwę w pracy resortu służby zagranicznej"74. Ōta natomiast był dyplomatą, który podjął pracę w MSZ w Tokio już w 1928 roku $^{75}$. Pełnił m.in. funkcje: attaché w ambasadzie Japonii w Londynie (1930), wicekonsula w Sydney (1931), trzeciego sekretarza przy ambasadzie w Moskwie (1937), a następnie do końca wojny zajmował różne stanowiska w MSZ. Po wojnie był m.in.: burmistrzem miasta Yokosuka (1947), pracownikiem Ministerstwa Transportu (1949) i MSZ (od 1954). W 1955 roku został ambasadorem w Birmie.

69 Zob.: „Trybuna Ludu” 1957, 5.19, s. 2.

70 GGS, A' 1.3.3.5-1, cz. 2, s. 71.

71 Notatka dla Tow. Ministra Naszkowskiego, dyr. Departamentu V Stuczański [w:] AMSZ, Departament V, Wydział III, Japonia 091. Sprawy organizacyjno-personalne projektowanej Ambasady PRL w Tokio, 1957, zespół 12, teczka 368, wiązka 15, s. 23.

72 Stosunki dyplomatyczne Polski 1944-1982 r. Informator, t. IV, Ministerstwo Spraw Zagranicznych, Departament Archiwum i Dokumentacji Historycznej, Warszawa 1984, s. 102. Por:: Gaimushō shokuin rekininhyō (Lista pracowników zatrudnionych w MSZ), Tōkyō 2007, s. 295. Warto dodać, że Dōshō był praktykantem w ambasadzie Japonii przed wojną, w 1939 r., a przyjechał z dwoma innymi pracownikami sprzed wojny, którzy znali język polski.

73 Ibidem; według listy w: Stosunki dyplomatyczne..., było to 10 stycznia $1958 \mathrm{r}$.

${ }^{74}$ Notatka Stuczańskiego z 12.03.1957 [w:] AMSZ, Departament V, Wydział III, Japonia 091. Sprawy organizacyjno..., s. 3.

75 AMSZ, Departament V, Wydział III, Japonia 08..., s. 39. 
Zaczynał się nowy okres w oficjalnych stosunkach polsko-japońskich. Jednak trwająca nadal zimna wojna nie sprzyjała ich szybkiemu rozwojowi, szczególnie w sprawach politycznych. Podział na obozy oraz fakt włączenia Polski i Japonii do każdego z nich utrudniał z pewnością te kontakty, podobnie jak brak dokładnej wiedzy o wewnętrznej sytuacji Japonii i jej kulturze politycznej w Polsce. Dotyczyło to również braku wiedzy o Polsce w Japonii. Na zakończenie, jako dobry dowód na taką sytuację, warto przytoczyć fragment tajnej depeszy z 2 kwietnia 1958 roku, nadanej przez ambasadora Żebrowskiego do dyrektora Słuczańskiego ${ }^{76}$ :

Przyjechałem do kraju, o którym - jak wiecie - nie można było w Warszawie zebrać żadnych prawie wiadomości. Także na miejscu nie zastałem żadnych „,przedaktów”, dotyczących zarówno spraw, jak i ludzi. Natomiast pobieżne choćby zetknięcie się z sytuacją w Japonii nakazuje ocenić stosunki tutaj jako bardzo politycznie skomplikowane, a kontakty z ludźmi, które mogłyby przynieść natychmiastową korzyść, jako bardzo trudne.

Składa się na to przede wszystkim złożona struktura tutejszego życia politycznego, wielość wzajemnie zwalczających się frakcji i koterii nie tylko we wszystkich partiach politycznych, ale nawet i w Ministerstwie Spraw Zagranicznych. Jest to między innymi również powodem niejasnego stanowiska sfer rządowych w wielu istotnych sprawach politycznych [...]. Ta specyficzna sytuacja życia politycznego Japonii nakazuje nam zachowanie szczególnej ostrożności zarówno w rozmowach z tutejszymi działaczami politycznymi, jak i w ocenie uzyskiwanych informacji. [...] Nie bez znaczenia są również trudności językowe i swoiste obyczaje, które opóźniają nawiązywanie i podtrzymywanie normalnych stosunków.

\section{BIBLIOGRAFIA}

\section{1. Źródła archiwalne}

Archiwum Akt Nowych, Warszawa.

Archiwum Ministerstwa Spraw Zagranicznych, Warszawa.

Archiwum prywatne Mori Mariko, Tokio.

Gaimushō Gaikō Shiryōkan (Archiwum Dyplomatyczne MSZ), Tokio.

\section{Dokumenty publikowane}

Database of Japanese Politics and International Relations Institute of Oriental Culture, University of Tokyo, Tokyo, http://www.ioc.utokyo.ac.jp/ worldjpn/documents/texts/ docs/19510908.T2E.html [dostęp: 10.01.2017].

„Dziennik Ustaw Rzeczypospolitej Polskiej” 1941, nr 8, Londyn.

Gaimushō shokuin rekininhyō (Lista pracowników zatrudnionych w MSZ), Tōkyō 2007.

76 AMSZ, Departament V, Wydział III, Japonia 091. Sprawy organizacyjno-personalne Ambasady PRL $w$ Tokio, 1958 r., zespół 12, teczka 375, wiązka 16, s. 1. 
Internetowa baza traktatowa MSZ, Warszawa, https:/www.traktaty.msz.gov.pl/bap.php [dostęp: 20.01.2017].

Nihon gaikō nenpyō narabi ni shuyō na bunsho 1840-1945 (Tablice chronologiczne i najważniejsze dokumenty dyplomacji japońskiej), t. 1, Tōkyō 1976.

Prawo międzynarodowe $i$ historia dyplomatyczna. Wybór dokumentów, oprac. L. Gelberg, t. 3, Warszawa 1960.

Stosunki dyplomatyczne Polski 1944-1982 r. Informator, t. IV, Ministerstwo Spraw Zagranicznych, Departament Archiwum i Dokumentacji Historycznej, Warszawa 1984.

Zbiór dokumentów, Polski Instytut Spraw Międzynarodowych, Warszawa.

\section{Prasa}

„Asahi Shinbun” 1957.

„Trybuna Ludu” 1955, 1957.

„Yomiuri Shinbun” 1954, 1957.

\section{Opracowania}

Haliżak E., Stosunki międzynarodowe w regionie Azji i Pacyfiku, Warszawa 1999.

Historia dyplomacji polskiej, t. 6: 1944/1945-1989, red. W. Materski, W. Michowicz, Warszawa 2010.

Kurihara T., Shiberia horyū-mikan no higeki (Jeńcy na Syberii - niekończąca się tragedia), Tōkyō 2009.

Pałasz-Rutkowska E., Romer A.T., Historia stosunków polsko-japońskich 1904-1945, Warszawa 2009.

Pałasz-Rutkowska E., Starecka K., Japonia, Warszawa 2004.

Pałasz-Rutkowska E., Starecka K., Kalendarium kontaktów polsko-japońskich, „Japonica" 2000, nr 12, s. 213-255.

Zarys dziejów Afryki i Azji 1869-1996. Historia konfliktów, red. A. Bartnicki, Warszawa 1996. 